\title{
Law and Heidegger's Question Concerning Technology: A Prolegomenon to Future Law Librarianship
}

\author{
Paul D. Callister*
}

"POOR librarians. Soon, no doubt, to go the way of blacksmiths and town criers, their chosen field made obsolete by Internet search engines and self-perpetuating electronic databases."1

\section{Introduction}

Following World War II, the German philosopher Martin Heidegger offered one of the most potent criticisms of technology and modern life. His nightmare is a world whose essence has been reduced to the functional equivalent of "a giant gasoline station, an energy source for modern technology and industry. This relation of man to the world [is] in principle a technical one . . . [It is] altogether alien to former ages and histories." ${ }^{2}$ For Heidegger, the problem is not

* Associate Professor of Law and Director of the Leon E. Bloch Law Library, University of Missouri-Kansas City School of Law. B.A., Brigham Young University, J.D., Cornell Law School, M.S.L.I.S., University of Illinois at Urbana-Champaign. The author thanks Elizabeth Bach-Van Horn, Richard Danner, James E. Faulconer, Erin Lavelle, Nancy Levit, Travis McDade and Yelena Shmidova for their excellent assistance and encouragement.

${ }^{1}$ Neil Genzlinger, The Fog of Facts, N.Y.TIMES, Oct.17, 2004, § 7, at 12, available at LEXIS, News Library, NYT File.

${ }^{2}$ Martin Heidegger, Memorial Address, in DIscouRSE ON THINKING 50 (John M. Anderson \& E. Hans Freund trans., Harper Torch Books 1966) (1959). 
technology itself, but the technical mode of thinking that has accompanied it. Such a viewpoint of the world is a useful paradigm to consider humanity's relationship to law in the current information environment, which is increasingly technical in Heidegger's sense of the term.

Heidegger's warning that a technical approach to thinking about the world obscures its true essence is directly applicable to the effects of current (as well as former) information technologies that provide access to law. The thesis of this article is that Heidegger provides an escape, not only for libraries threatened by obsolescence by emerging technologies, but for the law itself, which is under the same risks of subjugation. This essay explains the nature of Heidegger's criticisms of technology and modern life and explores the threat specifically identified by such criticism, including an illustration based upon systematic revision of law in Nazi Germany. The paper applies Heidegger's criticisms to the current legal information environment and contrasts developing technologies and current attitudes and practices with earlier Anglo-American traditions. Finally, the paper will consider the implications for law librarianship in the current information environment. 


\section{Heidegger's Nightmare: Understanding the Beast}

\section{A. Calculative Thinking and the Danger of Subjugation to a Single Will}

The threat is not technology itself; rather the danger to the modern world is based in the essence of thinking, which Heidegger describes as "enframing"3 or "calculative thinking." ${ }^{4}$ For Heidegger, the problem is that mankind misconstrues the nature of technology as simply "a means to an end."

Heidegger's articulation of the common conception of technology, as a "means," applies equally well to information technologies, including legal databases. True, it is hard to think of technology in any other way, but what Heidegger argues is that this failure to consider the essence of technology is a threat to humanity. An example of how Nazism reduced humanity to a thing to be ordered is discussed in Subsection B below.

Heidegger defines the threat in two ways: First, humans become incapable of seeing anything around them as but things to be brought into readiness to serve some end (a concept he refers to as "standing reserve"). ${ }^{6}$

3 See William Lovitt, Introduction, in MARTIN HEIDEGGER, QUESTION CONCERNING TECHNOLOGy AND OTHER EsSAYS, at xxix (William Lovitt trans., Garland Publ'g 1977) (1955).

${ }^{4}$ Memorial Address, supra note 2, at 46.

${ }^{5}$ Id. at 4.

${ }^{6}$ See Lovitt, supra note 3 ("Today all things are being swept together into a vast network in which their only meaning lies in their being available to serve some end that will itself also be directed toward getting everything under control. Heidegger calls this fundamentally undifferentiated supply of the available the 'standing reserve."'). 
Humans are cut off from understanding the essence of things, and consequently their surrounding world. ${ }^{7}$ Second, man has been reduced in his or her role to the "order-er" of things, specifically to some purpose or end, and as a result risks becoming something to be ordered as well. ${ }^{8}$

Heidegger illustrates these concerns as follows:

The forester who, in the wood, measures the felled timber and to all appearances walks the same forest path in the same way as did his grandfather is today commanded by profit-making in the lumber industry, whether he knows it or not. He is made subordinate to the orderability of cellulose, which for its part is challenged forth by the need for paper, which is then delivered to newspapers and illustrated magazines. The latter, in their set configuration of opinion becomes available on demand. ${ }^{9}$

In other words, the trees, the wood, the paper, and even the forester (whose ancestors once understood the sanctity of the woods) are ultimately subordinated to the will to establish orderly public opinion. The forester, in proverbial fashion,

${ }^{7}$ See HEIDEGGER, supra note 3, at 28 ("The rule of Enframing threatens man with the possibility that it could be denied to him to enter into a more original revealing and hence to experience the call of a more primal truth.").

${ }^{8}$ Id. at 27. ("As soon as ... man ... is nothing but the orderer of standing-reserve, then he comes to the very brink of a precipitous fall; that is he comes to the point where he himself will have to be taken as standing reserve.").

${ }^{9} I d$. at 18 . Heidegger finds that man is never completely "transformed into mere standing reserve" because of his unique position as the "order-er" of every thing else. Id. 
"cannot see the forest for the trees." Instead of appreciating the majesty and mystery of the living forest, he sees only fodder for the paper mill, which will pay for his next meal.

The same cynicism might be applied to legal publishing. Whole forests have given their lives to the publication of legal information in order to provide a stable basis for society--after all, the "law must be stable and yet it cannot stand still, ${ }^{10}$ or as our comrades from Critical Legal Studies would put it, law is simply a tool "to perpetuate the existing socioeconomic status quo."11 Cadres of West editors (commonly referred to in generic fashion as human resources, ironically making them all the less human $)^{12}$ work feverishly to digest points of law and assign 55,000 cases into a taxonomy with over 100,000 class distinctions, ${ }^{13}$ and all for the sake of predictable legal system and stable society.

${ }^{10}$ Roscoe Pound, INTERPRETATIONS OF LEGAL HISTORY 1 (1923).

${ }^{11}$ BLACK'S LAW Dictionary 382 ( $7^{\text {th }}$ ed., 1999). For a more thorough definition of Critical Legal Studies, see John Henry Schlegel, Critical Legal Studies, in OXFORD COMPANION TO AMERICAN LAW 202 (Kermit L. Hall ed., 2002).

12 HeIDEgGer, supra note 3, at 18 ("If man is challenged, ordered, to do this, then does not man himself belong even more originally than nature within the standing-reserve? The current talk about human resources, about the supply of patients for a clinic, gives evidence of this.").

${ }^{13}$ See Paul Douglas Callister, Beyond Training: Law Librarianship's Quest for the Pedagogy of Legal Research Education, 95 LAW LIB. J. 7, 21 (2003) (estimate of number of cases being published in West system in print). I learned that West's taxonomy has over 100,000 in a conversation with Dan Dabney, West's Senior Director for Research and Development, at an 
For Heidegger, the threat is revealed in mankind's perpetual quest to gain mastery over technology. "Everything depends on our manipulating technology in the proper manner as a means. We will, as we say, 'get' technology 'spiritually in hand.' We will master it. The will to mastery becomes all the more urgent the more technology threatens to slip from human control." ${ }^{14}$ When Heidegger published these words (first in 1962, but based on lectures from 1949 and 1950), ${ }^{15}$ the implications of nuclear energy and atomic warfare occupied much academic discussion. Heidegger points out that the popular question of this period did not concern how to find sufficient energy resources, but "[i]n what way can we tame and direct the unimaginably vast amounts of atomic energies, and so secure mankind against the danger that these gigantic energies suddenlyeven without military actions_-break out somewhere, 'run away' and destroy everything?"16 The modern question is about our mastery over technology, not about sufficiency of resources.

AALL convention. Interestingly, Dabney has recently expressed concern that large systems such as the West Topic and Key Number System are limited in effectiveness to their current 100,000 classes. See Dan Dabney, A Brief Practical Introduction to Taxonomies, Thompson Legal Knowledge and Trends White Paper 7, available at http://www.thomson.com/cms/assets/pdfs/legal/westkm_Taxonomies.pdf (last visited Sep. 15, 2007). Apparently, humanity's role as the order-er of things is "at capacity," and is, presumably, in need of technological replacement. See supra note 9.

${ }^{14}$ HeIDEgGER, supra note 3 , at 5 .

${ }^{15}$ Lovitt, supra note 3 at ix.

${ }^{16}$ Memorial Address, supra note 2, at 51. 
Similar concerns are manifest with respect to information technologies, where the primary problem is not lack of access, but too much access--for example, illegal music file swapping ${ }^{17}$ the anti-circumvention provisions of the DMCA $;{ }^{18}$ the trends to use licensing to control and preserve economic value of information (and to prohibit otherwise lawfully competitive practices, such as reverse engineering) $;^{19}$ and with respect to the field of law and government; retraction of government documents; ${ }^{20}$ the Patriot $A c t ;{ }^{21}$ the furor over "non-

${ }^{17}$ David Shepardson, Sony, Others Sue 9 U-M Downloaders; Record Companies Accuse Students of Taking Music Illegally .

${ }^{18} 17$ U.S.C. § 1201 (a) and (b) (

${ }^{19}$ Compare Davidson \& Assocs. v. Jung, 422 F.3d 630 (8th Cir. 2005) (end-user license agreement validly prohibited reverse-engineering even when copyright law may have permitted it) with Sony Computer Entertainment, Inc. v. Connectix Corp., 203 F.3d 596 (9th Cir. 2000) (reverse-engineering was permitted under fair use when no end-user license agreement restrictions banning the practice were an issue in the case).

${ }^{20}$ See, e.g., U.S. Government Printing Office, Statement on Request to Withdraw USGS Source-Water CD-Rom from Depository Libraries, News Release No. 02-04, Jan. 16, 2002, available at http://www.access.gpo.gov/public-affairs/news/02news04.html.

${ }^{21}$ Uniting and Strengthening America by Providing Appropriate Tools Required to Intercept and Obstruct Terrorism Act of 2001, Pub. L. No. 107-56, 115 Stat. 402 (codified as amended in scattered sections of 18, 50 and other titles of the U.S.C.). See also USA PATRIOT Improvement and Reauthorization Act of 2005, Pub. L. No. 109-177, 120 Stat. 192 (codified in scattered sections of 18,50 and other titles of the U.S.C.). 
published," electronic precedent, ${ }^{22}$ and the recent frenzy of e-discovery. ${ }^{23}$ Some of the stakeholders seemed to have liked things much better when information resources were scarce. ${ }^{24}$ Universal access is destabilizing—hence, the

${ }^{22}$ Molly McDonough, Door Slowly Opens for Unpublished Opinions, 5 A.B.A. J. EREPORT 16 (2006) (Supreme Court announces rule permitting citation of unpublished opinions.). "Judges and lawyers opposed to the citations have referred to unpublished opinions as 'junk law.' They flooded the advisory committee with some 500 letters opposing the citation rule." $I d$. at . See also Stephanie Francis Ward, Giving Their Opinions, 3 A.B.A. J. EREPORT 163 (2004) (Quoting federal $9^{\text {th }}$-Circuit Judge Alex Kozinski, "Given the press of our cases, especially screening cases, we simply do not have the time to shape and edit unpublished dispositions to make them safe as precedent."; Paul Marcotte, Unpublished but Influential: With Technology, Opinions not in the Law Books can be Misused, Critics Charge, 77 A.B.A.J. 26 (2001) ("[Lauren] Robel fears, for example, that bar groups and scholars will be unable to discern trends in case law covering federal agency decision-making because of the growing numbers of unpublished opinions.").

${ }^{23}$ See, e.g., Carolyn Southerland, Electronic Discovery: Ignorance of its Minutiae no Excuse for Litigators, 28 NAT'L L.J., Jul. 17, 2006, at S3; Kristin M. Nimsger \& Michele C. S. Lange, $E$ is for Evidence: Examining Recent E-Discovery Developments 23 GEN. PRAC. SOLO 40 (2006); James M. (Duke) Johnston Jr. \& Philip A. Whistler, E-Discovery: A Critical Litigation Issue for Franchisors and Franchisees, 26 FRANCHISE L.J. 20; Marianne Tolomeo and Brett Kuller, Litigation Strategies In Light of Document Retention Requirements for Electronic Records, 19 TRIAL. PRAC. 6 (2005); David K. Isom, Electronic Discovery: New Power, New Risks, 16 UTAH B.J. 8 (2003).

${ }^{24}$ The issue is discomfort with the pace of technological change (specifically the speed and accuracy of the Internet) and its impact on entertainment industries. See, e.g., Privacy and Piracy: The Pardox of Illegal File Sharing on Peer-to-Peer Newtorks and the Impact of the Technology on the Entertainment Industry: Senate Hearing 275 Before the Subcom. on 
considerable interest in getting a "handle" on technology through legal sanction and yet additional technological innovation (the so-called "access control" technologies). ${ }^{25}$

Permanent investigations, $108^{\text {th }}$ Cong. 18 (2003) (Jack Valenti testified: "If we just stopped right now [referring to development of broadband Internet], if the world just stopped, we would be doing fine because we [the motion picture industry] could survive it."). Mr. Valenti was particularly concerned about the future speed of the Internet.

Scientists at CalTech have announced "FAST," an experimental program that can download a DVD quality movie in five Seconds! Can anyone deny that these huge download speeds brood over our future? Can anyone deny that when one can upload and download movies in seconds or minutes the rush to illegally obtain films will reach "pandemic stage?"

Id. at 91-92 (prepared statement of Jack Valenti, Preseident \& CEO, Motion Picture Association) (emphasis added). The real problem is a lack of scarcity or "friction" in the new technologiesthey are simply too accurate and fast. See Siva VAIDHYANATHAN, ANARCHIST IN THE LIBRARY: How the Clash Between Freedom and Control is Hacking the Real World and Crashing the SYSTEM at ix ("Friction" concerns "how closely we should try to make cyberspace conform to and resemble the analog world ... "), xiii ("[T]he collapse of inconvenience has sparked a series of efforts that could reestablish the distance, or friction, that our information systems have featured since the rise of moveable type and bound books."), 13 (Explaining Robert Kaplan's theories in The Coming Anarchy (2000) as resulting from "too many dangerous goods, services, and ideas" flowing "without traditional regard for authority and tradition. . . ."), and 87("The fundamental purpose of intellectual property law is to create artificial scarcity.") (2004).

${ }^{25}$ See, generally VAIDHYANATHAN, supra note 24 . "Despite the obvious futility of antipiracy efforts, governments throughout the world are shifting to the technological regulation of distribution from the human to the technological, and expanding the jurisdiction from the national 
Heidegger's genius is that he recognizes that all the fuss about mastering technologies, although close to the mark, concerns the wrong issue. The more insidious threat is not nuclear fallout or economic devaluation of intellectual property, but the worldview of "calculative" thinking that accompanies rapid technological change: "The world now appears as an object open to attacks of calculative thought, attacks that nothing is believed able any longer to resist." ${ }^{26}$ For Heidegger, calculative thought is not limited to the manipulation of machine code or numbers. Rather, the concept is grounded in "Machiavellian scheming" and the pursuit of power. "Calculative thinking computes. It computes ever new, ever more promising and at the same time more economical possibilities. Calculative thinking races from one prospect to the next." ${ }^{27}$ The threat Heidegger envisions to human thought is even more dangerous than nuclear warfare. ${ }^{28}$

Heidegger's threat is based on the separation of man from his or her nature. By pursuing economic calculation, man is cut off from the transformative powers of his or her environment. In such a world, law does not have the

to global." Id. at 101. See also LAWRENCE Lessig, Code AND Other LAWS OF CYBerSPACE (1999); LaWrence Lessig, Future of Ideas: The Fate of the Commons in a Connected World (2001)

${ }^{26}$ Memorial Address, supra note 2, at 50.

${ }^{27}$ Id. at 46.

${ }^{28}$ Id. at 52 ("[A]n attack with technological means is being prepared upon the life and nature of man compared with which the explosion of the hydrogen bomb means little."). 
capacity to educate or to provide the basis for social harmony; ${ }^{29}$ rather, law like any resource must be employed to more economic ends. The implication is that calculative thinking mandates everything (including law) be subjected to a single will. While Heidegger recognized the danger of subjection of everything to a single will, the issue of whether, and when, he equated the danger with Nazi totalitarianism, which he had originally supported, would require a line of historical inquiry far beyond the scope of this article. ${ }^{30}$ Regardless of

${ }^{29}$ See infra notes 78-81 and accompanying text.

${ }^{30}$ One of the best treatments of the issue is Safranski's critique of Heidegger's responses to his famous interview with Der Spiegel, which took place on September 23, 1964 in Freidenburg, but which was not published until his death. See RüDIGER SAFRANSKI, MARTIN Heidegger: Between Good And EVIL 418-21 (Ewald Osers Trans. 1998). Safranski believes Heidegger recognized that Nazism had ultimately been guilty of technological reductionism, as used in this article (or reducing the world, including men, to a resource for exploitation). See id. at 420 ("Heidegger pointed out that National Socialism had originally intended to oppose such a development [technological reductionism] but had subsequently become its motor."). In a review of The Heidegger Controversy: A Critical Reader, Thomas Sheehan is much more skeptical of how far (and how soon) Heidegger distanced himself from his initial embrace of Nazism. See Thomas Sheehan, A Normal Nazi, 40 N. Y. ReV. OF Books, Jan. 14, 1993, at _, available at http://www.nybooks.com/articles/2701 (last visited on Sept. 11, 2006).

Heidegger's disillusionment had to do with the [Nazi] party's failure to carry out Heidegger's own philosophical program of renewing the promise of the ancient Greek polis, overcoming European nihilism, and returning to Germany to a less hectic and more simple life. Thus his so called "break" with official Nazism in the mid-Thirties consisted in 
Heidegger's own political and moral journey, Nazism effectively illustrates

Heidegger's philosophical fear-that technological thinking risks the "ordering" of all the world, including humanity, as resource subject to a singular will.

\section{B. Subjection of Law to Will-The Nazi Experience}

While serving as a law librarian at the University of Illinois at UrbanaChampaign, I learned that a special mission of the Library of Congress had seized contents of Nazi libraries following World War II. As part of a library lecture series, university librarians from the Modern Languages and Linguistics Library, Tom Kilton and Gail Hueting, discussed items seized by the Library of Congress and distributed to various American libraries. Some of the items were held in various University of Illinois campus libraries, but at the time of Professors Kilton and Hueting's presentation, no one had looked seriously at the law school. Motivated by the lecture and with some effort, I was able to identify over seventy

his decision to be more true to the "inner truth and greatness" of the movement that the party every could be.

Id. at__ (citing ERnst Nolte, Martin Heidegger, Politik und Geschicte in Leben und Denken (Polticts AND HISTORY IN HIS LIFE AND THOUGHT) 164-65 (1992). For general discussion of Heidegger and his affiliation with Nazism, see SAFRANSKI, supra; Sheehan, supra; NOLTE, supra; Johannes Fritsche, Historical Destiny and National Socialism in Heidegger's Being and Time (1999); Hugo Ott, Martin Heidegger: A Political Life (Allan Blunden, trans. 1993); Hans Sluga, Heidegger's Crisis: Philosophy and Politics in Nazi Germany (1993); Heidegger Controversy: A CRITICAL ReAder (Richard Wolin, ed 1991);. 
such items at the law library, and many other legal titles that traced their origin to Nazi Germany. ${ }^{31}$

As I made my way through some of the legal materials, I was struck by the fact that the Nazis did not simply ignore law; rather, they systematically rewrote it to their own purposes. For example, consider the following translation of a Nazi business organizations statute:

The industrial concern of a legal person is considered as Jewish,

(a) if one or several of the persons appointed as legal representation or one or several of the members of the supervisory board are Jews;

(b) if Jews are crucially involved as to capital or right to vote.

Crucial participation in capital occurs if more than one quarter of the capital belongs to Jews; crucial participation as to right to vote occurs if the Jewish voices (voters) reach half of the total number of voices (voters). ${ }^{32}$

${ }^{31}$ See generally, Library Lines: A Reminder to Never Forget the Past, ILL. JURIST, Spring 2002, at 25-26; Gail Hueting, Special Collections in German Studies in North American Libraries (rev. 2005), http://www.dartmouth.edu/ wessweb/gdgspeccoll.html (item no. 16, National Socialist Literature, briefly describes the 17,000 volumes held by the University of Illinois as part of the Cooperative Acquisitions Project for Wartime Publications).

32 HeinRich Schönfelder, Deutsche ReichsgesetZe Sammlung des Verfassungs, Gemein, Straf und VerfahrensRechts für den Täglichen Gebrauch § 10a (13th ed., 1943) (passage translated by this author). 
The section then goes on to address issues of subsidiaries and mining enterprises. ${ }^{33}$ Having been a tax attorney in a former life, I am struck by the technical precision and lengths to which Nazi draftsmen went to define "Jewish" business entities. Technical definitions of "controlled groups" and "closely held" corporations illustrate similar precision in draftsmanship with respect to U.S. tax law, but without the anti-Semitism. ${ }^{34}$ The Nazis, at least in 1934, did not simply ignore the law; they reworked it with great care and precision to their own ends.

A Nazi legal academy, complete with law professors, some of whom sported Nazi pins or armbands, systematically set about to rewrite the law according Nazi ideals. ${ }^{35}$ From a translated forward to the Academy for German Law Yearbook 1933/34, Dr. Hans Frank, Director of the German Academy of

${ }^{33}$ Id.

${ }^{34}$ See, e.g., 26 U.S.C. §§ 447(h) and $1563(\square)$.

${ }^{35}$ See, e.g., AkAdemie für Deutsches ReCht, Jahrbuch 1936, at vi-vii, illus. li (Dr. Hans Frank in Nazi Uniform as President of Academie für Deutsches Recht) and 144-45, illus. vi (Dr. Karl Lasch, Director of the Academie, sporting a Nazi lapel pin). Note that in 1936 Heidegger declined to attend a Descartes conference in France with the German delegation intended as a forum to reconcile Nazi socialism with European philosophy. See SAFRANSKI, supra note 30, at 324-25 (Ewald Osers trans., Harvard University Press 1998) (1994). Many of the German academia wore Nazi uniforms. Id. at 325. 
Justice, reveals his own "instrumental" ${ }^{\text {"6 }}$ attitudes about German law and legal academia when he writes:

Being entrusted with the Fuhrer's call for the revision of the German empire's legal system, . . . I have the Academy for German Justice, which shall demand the reorganization of the German legal life in close and lasting conjunction with the proper authorities for the legislation of the National Socialist program .... .

... Germany has at its disposal the greatest jurist's organization of the world, the Union of National Socialist German Jurists, to set down a method of working, which differs from the lawmaking of fundamental liberalist aims. In hardly any other area of life has the parliamentary methods of the party state had a more fatal effect than in the field of the lawmaking and legislation. ${ }^{37}$

In other words, the law was too important a tool to be entrusted to politicians. ${ }^{38}$ Both law and legal academia were put to the service of the Nazi "machine."

${ }^{36}$ Throughout this article, I use "instrumental" in the same sense as Heidegger uses "technical" or "calculative" to refer the reduction of law and legal information to "resources" to be ordered to some end. See supra notes 4-8 and accompanying text.

${ }^{37}$ Hans Frank, Vorwort, in AKAdemie FÜR DeUtSChEs ReCHT, JAHRBUCH 1933/34, at 5-6 (passage translated by this author).

${ }^{38}$ See id. ("Here, in the past, the former state's anonymous playground accounted only to extracted economic and political power groups."). 
As Führer, Hitler was exalted to the status of a legal concept. In 1940, J. Walter Jones (Fellow of Queen's College at Oxford) described the Führer as one of two principles upon which the Nazi conception of law was based (the other principle being racial homogeneity). ${ }^{39}$ Having reviewed Nazi writings on the subject, Jones observes:

The efficiency of all political and legal machinery is judged by the smoothness and speed which it brings to the functioning of the Nation State. Action, instant and overwhelming, must be the primary purpose of the State. ... Therefore, State action is dependent on the existence of a Leader (Führer) and on unquestioning faith in the creed of leadership." ${ }^{40}$

This nice little syllogism justifies totalitarian rule on the basis of expedient state action.

In June, 1934, the same Dr. Hans Frank, then the Bavarian Justice Minister as well as Director of the Academy of German Justice, phoned Hitler to inquire about the "legal grounds" to carry out Hitler's order to execute nineteen leaders of the Brownshirts (the Röhm putsch), then being held in Frank's care. Hitler's response: "I'll tell you that the legal grounds for everything that happens

${ }^{39}$ See J. WALTER JONES, NAZI CONCEPtION OF LAW 4-5 (Pamphlets on World Affairs, Series No. 21, 1940).

${ }^{40}$ Id. at 5. 
is the very existence of the Reich!" ${ }^{41}$ Being thoroughly converted to Hitler's cause, Dr. Frank would later declare, "[S]ince the foundation of the National Socialist State is National Socialist law and order, the Supreme Führer is by definition also our supreme judge, that his will must now be the foundation of our law and order." ${ }^{42}$ The nightmare of the world as gasoline station was realized into the rule of a single will.

Returning to Dr. Frank, not surprisingly the jurist closed his telephone conversation with Hitler by committing to carry out the executions; ${ }^{43}$ the German concept of order (in the sense of laying the foundation of the Third Reich) demanded it. Later, as Governor of occupied Poland, Dr. Frank would extend the same reasoning from nineteen to seventeen thousand: "We must not be squeamish when we hear of seventeen thousand Poles executed." ${ }^{44}$ Dr. Frank, who began his career as a defense attorney, and then progressed to a legal academic, would ultimately be convicted at Nuremburg and hung for his actions as governor of occupied Poland. ${ }^{45}$

${ }^{41}$ NiKLAS FRANK, IN THE SHADOW OF THE REICH 85 (Arthur S. Wensinger \& Carole ClewHoey trans.,1991) (1975) (Hans Frank's son recounted the phone conversation in an impassioned biography condemnation of Hans Frank's life and deeds as a jurist and Nazi officer.).

${ }^{42} I d$. at 72 (parenthetical comments of biographer omitted) (emphasis added).

${ }^{43}$ Id. at 85.

${ }^{44}$ Id. at 128.

${ }^{45}$ See generally, FRANK, supra note 41. 
The point of this painful odyssey through Nazi law is to illustrate the extremes to which law can be reduced to serve some end and be subjugated to a single will. In the words of Dr. Hans Frank, "the Academy for German Law in almost all important fields of law has supplied an abundance of valuable suggestions and contributions for the realization of the National Socialist legal will. ${ }^{46}$ It is to the realization of will that law, when reduced to the status of a technological tool as a result of calculative thinking, ultimately succumbs.

\section{The Modern American Version_Law and the Billable Unit}

In contemporary America, the technological yoking of law to will-its whole scale conversion to "standing reserve"-is infinitely less inimical and perceptible than in Nazi Germany, but the danger is there, nonetheless. It is the subtle shift in attitudes that accompanying new legal technologies to which law librarians, and ultimately the legal profession, must direct their attention.

While describing an experimental system that seamlessly combines brief writing on the word processor with legal research—to facilitate a kind of selfresearching brief-Dr. Dan Dabney, Senior Director of Research and Development, Thomson West, observes: "[W]hat is happening here, at least potentially, is that legal research has ceased to be a particularly separate part of the operation. You can just sit down and write a brief and the authorities you

\footnotetext{
${ }^{46}$ Frank, supra note 37 , at 6 (emphasis added).
} 
need, the law that you are looking for, will find you. ${ }^{\text {"47 }}$ Dabney's education as an information scientist is apparent. He quite capably connects technological developments with search behavior.

More importantly, Dabney connects legal search behaviors with underlying attitudes about legal arguments. In fact, Dabney illustrates that the behavior and attitudes this new product (the self-researching brief) facilitates are not really new. He quotes a former law partner: "You know when I write a brief, I do the legal research last. I write the brief and when I see something that probably needs authority I just put in '(cite)' and go on and write something else. But you can make the argument because you know what the arguments are going to be." ${ }^{48}$ West's new technology is not really to blame for this attitude. After all, the technology simply facilitates the calculative thinking and culture already at the root of the legal profession. West and other publishers simply meet existing demand for information services and products that supply authority for the arguments legal practitioners have already decided to make.

Dabney's most interesting observation explores the philosophical underpinnings of such calculative attitudes.

${ }^{47}$ Dan Dabney, Envisioning the Future: The Publisher's Perspective, Future of Law Libraries Symposium, held by the Florida Coastal School of Law, Thompson West and InfiLaw System (Mar. 10-11, 2005), mms://broadcast.cali.org/foll05/DanDabney.wmv (quoted passage transcribed by this author).

${ }^{48}$ Id. 
$[T]$ he reason that my colleague was so proud of this is that it reflected his rather cynical attitude about the law itself. There is no sense in which the law informs you at all. You are creating the law that was necessary to your purposes on the fly and you were never going to discover that law wasn't the way you wanted it to be. This [is], you know, the legal realist mentality: There is plenty of law out there for everyone. ${ }^{49}$

The triumph of legal realism is facilitated by the information environment. Indeed, Grant C. Gilmore made the argument back in 1961 that realism is a reaction of the information environment to the presence of too many cases in the system. ${ }^{50}$

Even in the Anglo-American tradition, the same society that triumphed over Nazism and Fascism, the prevailing viewpoint is technological and calculative. Heidegger's fears are apt criticism of American capitalism as well as totalitarian ideologies: '“Calculation' stands for Americanism, 'planning' for communism, and 'cultivation' for National Socialism." ${ }^{51}$ The labels may differ but the methods of Western ideologies all share calculative thinking at their core.

Modern thinking about law is also calculative in nature. After all, the principle of flexible stability, the "[l]aw must be stable and yet it cannot stand

${ }^{49} / d .($ emphasis added).

${ }^{50}$ See Grant Gilmore, Legal Realism: Its Cause and Cure, YALE L.J. 1037, 1041, 1045 (1960-61).

${ }^{51}$ SAFRANSKI, supra note 30, at 296. 
still,"52 the oft-recited declaration with which Roscoe Pound opens Interpretations of Legal History, and which is engraved above the moot courtroom at Cornell Law School, facilitates predictability, economic growth, and the general welfare. While Pound's quote has been elevated to the status of a legal maxim, what is less known is the underlying rationale. "The social interest in general security has led men to seek some fixed bases for an absolute ordering of human action whereby a firm and stable social order might be assured." ${ }^{53}$ Again, it is the will to order which drives modern, instrumental conceptions of law. ${ }^{54}$ Law is simply the basis for "ordering human action," although as Pound argues, the resulting construct must be flexible to be successful. Heidegger's description of technical and calculative thinking, based upon willing order, corresponds nicely to this modern conception of law.

Turning to other modern theorists, the conception of law is equally calculative and instrumental in nature. Ronald Dworkin's paradigm of law as the unending chain story also functions to maximize the values of stability and predictability. ${ }^{55}$ Another luminary of jurisprudence, H.L.A. Hart stresses law's "value as an instrument for the realization of human purposes." ${ }^{56}$ Normative

${ }^{52}$ Pound, supra note 10.

${ }^{53}$ Id. (emphasis added).

${ }^{54}$ Id.

${ }^{55}$ See generally, RONALD DWORKIN, LAW'S EMPIRE 228-38(1986)

${ }^{56}$ H.L.A. Hart, Problems of Philosophy of Law, in INTRODUCTION TO JURISPRUDENCE 136, 136-37 (Lord Lloyd of Hamstead ed., $4^{\text {th }}$ ed. 1979). 
theories of law and economics exult in the efficient administration of the general welfare. ${ }^{57}$ Noting law's instrumental character, Richard Posner comes closest to identifying the technological nature (in Heidegger's sense) of law, by arguing: "I myself do not think law is a humanity. It is a technique of government." ${ }^{58}$ Oliver Wendell Holmes, Sr., noted poet and father of the eminent Supreme Court Justice, also saw law in a technical and instrumental context: "Law is an implement of society which is intended for every-day work." ${ }^{59}$ Holmes, Jr., while not using technical language, comments on the historical origins of law saying that "the earliest appearance of law was as a substitute for the private feuds between families or clans.." ${ }^{10}$ In sum, the modern, instrumental conception of law is clear. Law is fundamentally a resource for stability in an unstable world. In Heidegger's terms, law appears as standing reserve-as something to be

${ }^{57}$ See Eric Talley, Theory of Law and Economics, in OXFORD COMPANION TO AMERICAN LAW 485, 486 (Kermit Hall ed., 2002)

${ }^{58}$ Richard A. Posner, Law and Literature: A Relation Reargued, 72 VA. L. REV. 1351, 1392 (1986) (Posner criticizes efforts in the law and humanities but agrees that as a technique, law is "tied to the creation of and interpretation of texts" which can benefit "from sympathetic engagement with literature," at least on his terms).

${ }^{59}$ Oliver Wendell Homes, Sr., Pages from an Old Volume of Life, in OLIVER WENDELL Holmes, JR. , 8 Works Of Oliver Wendell Holmes 323 (Standard Library ed., Scholarly Press 1972) (1892) (emphasis added) [Check page number in modern edition]. Holmes, Sr. continues: "It [law] is a course tool and not a mathematical instrument." Id.

${ }^{60}$ Oliver Wendell Holmes, Jr., Common Law 248 (LitTle, Brown \& Co. 1923) (1881). 
ordered, with the rest of the world to some end. ${ }^{61}$ Small wonder that, besides Heidegger's philosophical definition, standing reserve is, quite appropriately, a accounting concept for assessing resources in the military and energy industries. ${ }^{62}$

Reducing law to standing reserve may seem unnecessarily perfunctory, especially since it is hard to think of the law in any other way. Indeed, the profession speaks of legal information, like other information, as a resource to be mined, harvested, ordered, quantified (in billable units no less), packaged, marketed and ultimately consumed to some calculated end or purpose, which in turn will serve some other overarching end or purpose. A quick survey of product literature reinforces the commoditization of legal information and law:

${ }^{61}$ See supra note 6.

${ }^{62}$ See, e.g., David Newbery, Electricity Liberalization in Britain and the Evolution of Market Design, in Electricity Market Reform: An International Perspective 120 (Fereidoon Perry Sioshansi \& Wolfgang Pfaffenberger eds., 2006) (illustrating concept of energy reserves); M. Rashidinejad, Y.H. Song, \& M.H. Javidi, Ancillary Services I: Pricing and Procurement of Reserves, in Operation of MARKET-ORIENTEd PoWer Systems 232 (Yong-Hua Song \& Xi-Fan Wang eds., 2003) (illustrating concept of energy reserves); Carlos Pascual, State Department Office of Reconstruction and Stabilization, Remarks at Woodrow Wilson Center Discussion: United States Post Conflict Capacity (Oct. 20, 2004), at LeXISNeXIS Congressional, FederaL NEWS SERVICE (2004) (discussing role of foreign service supporting military through rotating through "Standing Reserve"). 
- "Try CQ Legislative Impact and you'll see how this service can streamline your work by pinpointing the exact places where pending legislation would change existing laws." ${ }^{\text {63 }}$

- Advertisement with photo of attorney in front of circus booth labeled, "Estrellas Prophecies." He asks, "How will my judge rule on this issue?" The subtitle for the advertisement reads, "There's a better way to get a real indication of how your judge might rule on a specific issue-strategic court-records research on LexisNexis Courtlink."

- "Draft high-quality, winning legal briefs, motions and pleadings faster and more accurately with Shepard's BriefCheck for the Web . . .".65

- 'When you need an answer to the question, 'Is my case good law?', there's no question which system provides a more comprehensive or more focused answer." 66

${ }^{63}$ Letter from Congressional Quarterly, Inc. (undated 2006) (copy on file with author).

${ }^{64}$ LexisNexis advertisement, 91 ABA JouRNAL, Feb. 2005, at 7 ("Revealing court-records research is just one way LexisNexis gives litigators a strategic advantage, often before their case ever goes to trial.").

${ }^{65}$ New Shepard's BriefCheck for the Web, 6 LEXIS NEXIS INFORMATION PROFESSIONAL UPDATE 93 (2006).

${ }^{66}$ Lexis Auto-Cite advertisement, 77 ABA JournAL, August 1991; 45 ("When it comes to building strong cases, there's strength in numbers [of precedent]."). 
- "Westlaw Litigator can help you in every aspect of your case and at every stage of the process. It puts all your key litigation resources in one place to save you time." ${ }^{n 7}$

- “Only ALR gives you the assurance you haven't missed any case on your point." ${ }^{n 8}$

- 'In addition to finding the primary law, you can check your firm's legal arguments against those of the legal profession's heavy hitters." ${ }^{\text {"69 }}$

- "Thanks to KeyCite and Table of Authorities, you can relax knowing that nothing affecting the precedential value of a cited authority will escape your notice..70

The common theme from the vendor literature is simple: legal information resources are essential tools, which make the practice of law more efficient. They even proffer competitive advantage and a sense of security. Furthermore, these information resources put the law at the users "finger tips" so that nothing is missed, or in Heidegger's terms, the resources bring law into the order of

\footnotetext{
${ }^{67}$ Westlaw Litigator advertisement, at 90 ABA JouRnAL, Mar. 2004, at 3.

${ }^{68}$ Lawyers Cooperative Publishing advertisement for ALR, 77 ABA JouRNAL, July 1991,
} at 15.

${ }^{69}$ Tim Nixon, How Online Briefs Save Time, 7 LAW LiBRARIANS IN THE NeW MilLENNIUM, May-Jun. 2004, at 7 (commenting on West's Online Briefs)

70 Jay Shuck, WestCheck Meets the World Wide Web, in 7 LAW LIBRARIANS IN THE NEW MiLLENNIUM, Mar.-Apr. 2004, at 5. 
standing reserve. As Dabney has pointed out, ${ }^{71}$ law appears to have the same characteristics as the information services that provide access to it because through such systems the law always stands ready to supply argument for any occasion or proposition. The question is how to possibly think otherwise. More importantly, has Heidegger's nightmare of the world as a "gasoline station" been realized?

\section{Daring to Think Otherwise-“"In-formative" Reading}

Dabney's use of inform (as in "there is no sense in which the law informs you") is quite interesting and entirely consistent with his behavioral approach, including conceptual linkages to legal realism. Information evolved from the Latin informare as in "the action of forming matter, such as stone, wood, leather, etc." or with respect to informing humans, "the action of informing; formation or molding of the mind or character, training, instruction, teaching; communication of instructive knowledge..72 To inform was transformative of character, with respect to material objects or the human mind and character. Following World War II, however, there was a shift to a more technical or calculating meaning (consistent with Heidegger's sense of term) of the term information to "define anything that was sent over an electric or mechanical channel. ${ }^{73}$ In 1949, pioneers of information sciences pioneers, Claude Shannon and Warren Weaver

\footnotetext{
${ }^{71}$ See supra note 49 and accompanying text.

${ }^{72}$ Richard SAUl WURMAN, INFORMATION ANXIETy 38 (1989).

${ }^{73} / d$.
} 
defined information as "that which reduces uncertainty." ${ }^{174}$ The utility of information having been established; it is now a proper "resource." Being dedicated to "reducing uncertainty," information bears remarkable relationship to order, or ordering, and fit easily with Heidegger's concept of "standing reserve."

The same is true of law. As discussed previously, legal information reduces uncertainty through providing access to a stable system of rules for resolving disputes in a predictable way. ${ }^{75}$ In short, law is the tool, perhaps the principle one, for ordering our world. It is no surprise that the law is often made up of "ord-inance" (deriving from order). ${ }^{76}$ Indeed, the German gesetz, translated as law, also means "to place" as in "to set down order." ${ }^{77}$ Returning to legal information, the major legal publishers facilitate this ordering in remarkable way, with "Exhibit A" being West's Topic and Key Number system.

The interpretation of information as a tool for reducing order, however, contrasts with the sense that Dr. Dabney may have meant for the term inform, which is in its pre-war, non-technological sense, of the information informing the reader. It is the individual user's understanding and character which is formed, molded and educated. It is in this sense that Isocrates and Plato referred to law:

${ }^{74}$ Id. at 39 (citing Claude Shannon \& WarRen Weaver, Mathematical Theory of COMMUNICATION (1949)).

${ }^{75}$ See supra notes 59 and accompanying text.

${ }^{76}$ See OXFORD ENGLISH DictionARY (Online Draft Revision Sept. 2004) (etymological entry for "ordinance").

${ }^{77}$ See id. ( $2^{\text {nd }}$ ed. 1989) (Online 2006) (etymological entry for "law"). 
"Isocrates claims that proliferation of laws and the search for akribeia ('precision') [perhaps anther reference to order] was to miss the real function of law, which was to be general and morally educative. ${ }^{\prime 78}$ Plato shared a similar vision with respect to law severing an instructional function and promoting social harmony. "Laws are partly framed for the sake of good men, in order to instruct them how they may live on friendly terms with one another, and partly for the sake of those who refuse to be instructed, whose spirit cannot be subdued, or softened, or hindered from plunging into evil..79 Plato's analogy of philosophy curing the ills of the soul like a doctor applying medicine to a sick patient is particularly apt here. ${ }^{80}$ "[J]ustice is a moral physician and cures men of their excesses and makes them better people." ${ }^{11}$ This is the original sense of legal information, which stresses informing or educating and molding members of society.

While browsing a well-known rare book store in Salt Lake City, I happened upon a third edition from 1633 of Lord Edward Coke's First Part of the Institutes of the Laws of England (otherwise known as the Coke's Commentary on

${ }^{78}$ S.C. Todd, The Language of Law in Classical Athens, in MORAL WORLD OF THE LAW 17, 22 (Peter Coss ed., 2000) (citing Isocrates §§ 7.33, 7.39-40). See also Paul D. Callister, Law's Box: Law, Jurisprudence and the Information Ecosphere, 74 UMKC L. REV. 263, 277-78 (pointing out the advantages of Stelae as a medium for education through law).

${ }^{79}$ Plato, Laws IX, in Dialogues of Plato 266 (Benjamin Jowett trans., MacMillan \& Co., 1892). [Search for quote in modern edition]

${ }^{80}$ PLATO, Gorgias (Walter Hamilton ed., Penguin Books, 1960, 1986 prtg.) 69-71

${ }^{81}$ Id. at 70 . 
Littleton) ${ }^{82}$ which I acquired for my law school. The volume is particularly valuable because of the marginalia, evidence of provenance, and other inscriptions, including one from the cover sheet bearing a quote in Latin from Quintilian from the first century A.D. This quote reveals something about the relationship of the reader to the text. "Those who strive to reach the heights will always rise higher than those who, giving up on their goals because of despair, immediately halt at the lowest levels." ${ }^{\prime 83}$ The quote is not a testimonial about the ease and usefulness of the book, or its utility as a "resource"; rather, it emphasizes the journey which the reader must undertake, and the transformation that is the ultimate reward of the book.

Professor Frederick Hicks, whose legacy as a legal bibliographer and teacher is dear to this profession, recognized the difficulty readers had with Coke's monumental work, remarking: "This 'painful volume,' has become a symbol for all books which, sparing neither author nor reader in going to the

${ }^{82}$ EdWARd Coke, FiRst PART OF THE INSTITUTES OF THE LAWS OF ENGLAND $\left(3^{\text {rd }} \mathrm{ed}\right.$. corrected, London, M.F.I.H. \& R.T. assigns of I. More, esq., 1633)

${ }^{83}$ Translation of handwritten inscription from dedication page of UMKC law library's copy of Coke's Institutes. See id. The inscription comes from Quintilian's Institutio Oratoria and reads: "Altius ibunt qui ad summa nitentur quam qui praesumpta desperatione qua velint evadendi protinus circa ima substiterint." Email from Holly M. Sypniewski, Ph.D., Department of Classics Studies, Millsapps College, to Elisabeth Bach-Van Horn, Legal Research Assistant, UMKC School of Law (Aug. 16, 2006). See 1 INSTITUTIO ORATORIA OF QUINTILIAN 14-15 (bk. I preface, I. 20) (E. Capps, T.E. Page, \& W.H.D. Rouse eds., H.E. Butler trans., London, William Heinemann 1920) (n.d.). 
bottom of things [and] say the last on the subjects of which they tread." 84 Fundamentally, the prominent legal texts in earlier times bore a different relationship to readers and students than the legal information resources of today. Prior texts emphasized in-forming the student. Modern texts are more easily accessed, perused, and searched in both print and digital (including convenient "cut-and-paste") formats.

This modern change in the relationship of readers to legal texts is demonstrated in Otto Preminger's film, Anatomy of a Murder ${ }^{85}$ In the film, which explores the insanity defense, or "irresistible impulse," the lawyer for the defense, Jimmy Stuart's character, Paul Biegler, does something incomprehensible in the modern practice of law. Mr. Biegler and his alcoholic colleague, actually choose to spend their leisure time drinking bourbon whisky and reading from case reporters_from decisions by Justice Holmes no less. ${ }^{86}$ For a practicing lawyer to find recreation in reading case reporters, let alone spend significant time to ponderously read cases under any circumstances (while tippling with a

${ }^{84}$ Frederick HiCKS, MEN AND BoOKS Famous IN THE LAW, 96-97 (1921)(1991 prtg.).

${ }^{85}$ ANATOMY OF A MURder (Carlyle Productions, Inc. 1959).

${ }^{86}$ Id. (Parnell queries Paul Biegler: "Well, what shall we read this evening? How about a little Chief Justice Homes?") 
colleague), probably strikes most present-day attorneys as anachronistic, if not an outright Hollywood fabrication. ${ }^{87}$

As unusual as the behavior of the fictional attorneys in Anatomy of a Murder may seem, there was indeed a time when reading (other than the condensed cases and heavily edited versions presented in the classroom) was dear to the profession. Professor Berring noted that "Daniel Webster probably read every case that was published by every American appellate court, and probably read English cases as well." ${ }^{" 88}$ In 1769, another model American, John Rutledge wrote a telling letter to his brother Edward, who was then studying law in England. The letter advises:

[W]ith regard to particular law books—Coke's Institutes seem to be almost the foundation of our law. These you must read over and over, with the greatest attention, and not quit him till you understand him thoroughly, and have made your own everything in him, which is worth taking out. ... I would read every case reported from that time [the Glorious Revolution of 1688] to the present [1769]. . . I I would have you, also, read the Statute Laws throughout .... When I say you should read such a book, I do not

${ }^{87}$ The 1959 movie is based on a book of the same title by John D. Voelker (writing under the name of Robert Traver) originally published in 1958. See Robert TRAVER, ANATOMY OF A MURDER (1958).

${ }^{88}$ Robert C. Berring, Collapse of The Structure Of The Legal Research Universe: The Imperative Of Digital Information, 69 Wash. L. Rev. 9, 19 (1994). 
mean just to run cursorily through it, as you would a newspaper but to read it carefully and deliberately, and transcribe what you find useful in it. ${ }^{89}$

Both John and Edward Rutledge would serve as Delegates to the General Congress prior to the American Revolution and later as governors of South Carolina. Edward Rutledge would sign the Declaration of Independence, and John would serve as a Justice on the Supreme Court and Chief Justice of the South Carolina Supreme Court. ${ }^{90}$ Other examples of equally prodigious readers of American law are easy to find. ${ }^{91}$

In any event, at the heart of an English and early American legal education, was reading, and not just perusing, but a painstaking, purposefully repetitive, and comprehensive study of works (as of 1769, eighty-one years of cases), resulting in extensive personal annotation and transcribed notes. So voracious was the reading of the nineteenth and early-twentieth century bar that courts justified selecting decisions for publications (rather than publishing every

89 John Belton O'NeAll, 2 Biographical SKetches of the Bench AND Bar OF SOUth CAROLINA 124-26 (Charleston, S.G. Courtenay \& Co. 1859).

${ }^{90}$ See id. at 17-19, 115, and 120. See also John Rutledge, in ENCYCLOPÆEIA BRITANNICA ONLINE, http://www.search.eb.com/eb/article-9064520 (last visited Oct. 17, 2006).

${ }^{91}$ See, e.g., Moorfield Storey And EdWARd W. EMERSon, EbeneZer Rockwood HoAR 30 (1911) (Mr. Hoar Served as Supreme Court Justice for Massachusttes); ILLINOIS STATE BAR Association, Address of Hon. Henry W. Blodgett upon the Early Bar of Chicago 6-7 (Chicago, Chicago News Co. 1896) (discussing reading habits of Illinois State Supreme Court Justice, John Dean Canton). 
decision) to help cut down the reading. "The leading lawyers in every State are expected to run over, if they do not read, every case in every new volume of its reports. Every case dropped [from publication] lightens the task." ${ }^{92}$ Indeed, law was the profession of readers. The question is why? Was it simply a matter of being the best armed for court or is there something deeper, more noble going on?

The very essence of being a lawyer was to be bookish. In a delightful article published in 1937, legal historian Max Radin explains the seventeenthcentury work of Sir Edward Coke and its effect on modern legal scholarship on the basis of its grounding in books. ${ }^{93}$ However, the purpose of such reading is best understood from Lord Coke himself. Coke's writings go beyond "making the case" to include something more beneficial, such as informing of the reader and improving individual self-governance in accordance with law. Coke quotes parliament about the reason for publishing his magnum opus, the Laws and Institutes, in English, rather than the customary legal French:

That the Lawes and Customes of this Realme the rather should be reasonably perceived and knowne, and better understood by the tongue used in this Realme, and by so much every man might the better governe himselfe without offending the Law. ... [G]ood governance and full right is done to every man, because that the Lawes and Customes be learned

92 Simeon E. BALdWIn, AMERICAN JUdiciary 274 (1905).

${ }^{93}$ Max Radin, On Legal Scholarship 46 Yale L. J. 1124, 1127 (1936-1937). 
and used in the Tongue of the Country": as more at large by the said Act . ... No man ought to be wiser than the Law. ${ }^{94}$

The highest purpose of publishing law is so that individuals may better govern themselves.

The moral essence and transformative character of law books is evidenced in several ways. For instance, early English judges and attorneys elected to read Littleton's Tenures each Christmas. ${ }^{95}$ Together with the Bible, such books came to represent individual conscience. In 1648, during the Interregnum, Judge David Jenkins was accused before the House of Commons of being a Royalist. In prospect of hanging, the Judge found strength in his books: "Multitudes, no doubt, will come to see [this] old Welsh Judge hanged. I shall go with the venerable Bracton's book hung on my left shoulder, and the Statutes at Large on my right. I will have the Bible, with a ribbon put round my neck, hanging on my breast." ${ }^{96}$ The symbolic moral force that an English judge

${ }^{94}$ COKE, supra note 82 , at vi.

${ }^{95} 2$ Westminster Hall or Professional Relics and Anecdotes of the Bar, Bench, AND WOOLSACK 8 (London, John Knight \& Henry Lacey 1825) (describing Roger North as the model

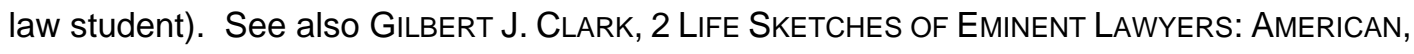
ENGLISH, AND CANADIAN 101 (Kansas City, Lawyer' International Co. 1895); HICKS, supra note 84, at 95 .

${ }^{96}$ William RalPh Douthwaite, GRAY'S InN: ITS HISTORY \& ASSOCIATIONS 212 (London, Reeves \& Turner 1886). 
placed upon the Bible, Bracton and the Statutes belies a reverence to legal bibliography alien to the modern practice of law.

Turning from legal information and bibliography to the law itself, the law has at various times in history functioned as a transformative agent, rather than as simply another instrument or resource for ordering the world. While this topic could only be addressed sufficiently in a paper exclusively devoted to that purpose, a few examples are in order. The thirteenth century Charter of Kurkukan Fuga (forming the Empire of Mali), as kept by oral tradition, provides for the division of classes, rules for collective escheat, transfer of property, fixing dowry, etc., but also for positive relations among family members, avoidance of vanity, respect for seniority, tolerance for religious beliefs, protection of foreigners, minimization of offenses against women, joking among classes, and description of ideal leadership. ${ }^{97}$ The point is that with the Charter of Kurkukan Fuga, there is little division between legal and normative standards which

${ }^{97}$ See Articles 1-4 (social classes), 7 (tolerance among relations), 14 (offense of women), 22 (vanity), 24 (treatment of foreigners), 29 (dowrey), 32 (acquiring property), 33 (escheat), and (43) (joking) of the Charter of Kurukan Fuga. See Magoné Niang, The Kurkukan Fuga Charter: An Example of Endogeus Governance Mchanism for Conflict Prevention 6-8(Sahel and West Africa Club/OECD, Inter-generational Forum on Enogenous Governance in West Africa, Working Document, Workshop No. 2, June 26-18, 2006),

http://www.oecd.org/dataoecd/60/55/37341473.pdf. See also Fatou K. Camara, Democracy in a Plural Society: The Charter of Kurukan Fuga (Empire of Mali - 1235), 8 (qualities of leadership), 9 (religious tolerance) (Salzburg Seminar, Session 435: The Rule of Law: Reconciling Religion and Culture in a Constitutional Framework, Oct. 9, 2006) (copy on file with author). 
modern legal practitioners and theorists would recognize. This ancient African law functioned in a way that transformed individuals by encouraging tolerance, respect, leadership, diversity, virtue and even humor.

Also drawing from Africa, the Egyptian Demotic Code of Hermopolis West (dating from about 730-715 B.C. in the Twenty Fourth Dynasty) is of the same tradition as both Egyptian wisdom literature and the narrative classic, the Tale of the Eloquent Peasant. ${ }^{98}$ Returning to Europe, the ancient Celts lacked a clear separation between legal maxim and aphorism or gnomic literature, ${ }^{99}$ intimating that a common tradition functioned in both fashions (to both resolve disputes and instruct character). Finally, the law functions in similar fashion in Classical Greece. Plato's Laws suggest that "solemn custom often prevails over that of statute."100 Indeed, "custom as promulgated orally in the medium of Homer's Iliad is an interweaving of both private and public codes of conduct." ${ }^{101}$ Thus, Homer's classic works may be as apt a source for law as any statute, and probably much more transformative in effective.

Moving to ancient Anglo-Saxon legal traditions, a quick survey of law suggests that it functioned merely as an efficient mechanism for administering

${ }^{98}$ See Callister, supra note 78 , at 293-94.

${ }^{99}$ Id. at 319-20.

${ }^{100}$ Eric A. Havelock, Preface to Plato 62-63.

${ }^{101}$ Callister, supra note 78, at 279 (citing HAVELOCK, supra note 100, at 76). 
punishments and avoiding violence, ${ }^{102}$ much as Holmes, Jr. had noted. ${ }^{103}$

However, the curious title of the fourteenth century code of customary law, known as the Sachsenspiegel (translated "Saxon Mirror)", suggests the need for much deeper understanding.

The mirror genre examines the metaphysical and intellectual dimensions of subjects such as virtue, law, and rulership. Such mirrors, written in Latin, informed and instructed the next generation. . . Eike's lawbook [Der Sachsenspiege/] fits this tradition, but, significantly it also marks the first such instructional prose text to appear in the vernacular. Eike borrowed the concept from the well-known twelfth-century mirror, Honorius Augustodunensis's Speculum ecclesiae, in which the Bride of Christ looks in a mirror to find those faults in herself that might be objectionable to Christ. ${ }^{104}$

102 See generally, LAWS OF THE EARLIEST ENGLISH KINGS (F.L. Attenborough ed. and trans., Clark, New Jersey, 2006) (1922); LAWS OF THE SALIAN AND RIPURIAN FRANKS (Theodore John Rivers trans. 1986). Similar comparisons can be made with other tribes of northern Europe. See Old WEST FRISIAN SKELTANA RIUCHT (Sydney Fairbanks trans. 1939); LAWS OF EARLY ICELAND: GRÁGÁS I AND II (Haraldur Bessason \& Robert J. Glendinning eds., Andrew Dennis, Peter Foote, \& Richard Perkins trans. 1980).

${ }^{103}$ See supra note 60 and accompanying text.

104 Introduction, in SAXON MIRROR: A SACHSENSPIEGEL OF THE FOURTEENTH CENTURY 7-8 (Ruth Mazo Karras \& Edward Peters eds., Maria Dobozy, trans., University of Pennsylvania Press 1999). 
In other words, the Saxon law, despite the plethora of rules and penalties

permitting resolution of disputes is fundamentally meant as text for the populous, in the vernacular, so that they might better measure themselves. It is law that is informative in nature.

In summation, it is possible to think about law and legal information as something other than resources for efficient exploitation. Not so long ago, even the modern study of law carried transformative impact. Law books were even worthy of perusal during one's leisure time, read out loud while sipping drinks with friends after working hours. Legal texts were the kind of reading one recommended to a friend or a close sibling, with the expectation that the literary adventure, although difficult, would exalt one's thinking and character. Legal education was a life long quest-the kind of journey that produced giants worthy of drafting constitutions and governing nations. It is thus possible to think otherwise about law and legal institutions.

\section{Prologue to Future Law Librarianship—Dealing With Obsolescence}

As the opening quote suggests, the emergence of information technologies has threatened modern librarianship with obsolesce, or at least the perception thereof. Furthermore, because of law's traditional dependence on highly structured repositories of legal information, the same threat applies to law and legal thinking. Law can also be thought of as a resource to be harnessed, 
exploited, and ultimately rendered obsolete. "Ask not for whom the bell tolls, it tolls for thee."105 The fates of libraries and law are intertwined.

Despite the gloom, the shared fates of law and libraries are predicated on a worldview that reduces their status, along with everything else, to mere resources, suitable for exploitation. However, this outcome is not foreordained, and the fundamental aim of every law library ought to be to remind its patrons and constituents to dare to think otherwise- - to see the law in its true, transformative essence. If law librarians do not play this important role, the battle may be lost entirely.

In fall of 2004, I participated in Salzburg Seminar, Libraries in the TwentyFirst Century. A product of the conference was a document entitled Vision of the Communal Role of Libraries. The statement emphasizes the role of libraries as cultural institutions.

The library is a place where knowledge and information freely dwell to define, empower, preserve, challenge, connect, entertain and transform individuals, cultures and communities. The dwelling place, whether physical or virtual, is the product of collective reflection, aspiration, commitment, expertise and organization. It is both a byproduct of civil communities and a catalyst for cultural progress, inspiration, expression and exchange. Its absence in this new century would not only deprive

105 John Donne, Devotions upon Emergent Occasions, XVII, in JOHN DONNE: SELECTED PoEtRy AND PROSE 166 (T.W. Craik \& R.J. Craik eds., 1986). 
many individuals of important resources, but also, more significantly, such loss would deny humanity an essential portion of its shared identity and entitled liberties. The library can never be fully replaced by information technologies. For the essence of its communal role is not the technological mastery over knowledge and information, but rather the provision of sanctuary for human thought and expression in any medium. ${ }^{106}$

The statement is intended to counter perceptions of libraries as obsolete resources and emphasizes the role of libraries as cultural institutions. Of particular importance is the role of libraries in defining and enabling communities and as serving as transformative institutions and sanctuaries for human thought and character. Despite their unique features, the same statement could be applied equally well to law libraries.

In conclusion, let me suggest four ways in which the legal academy and librarians can think about law libraries that will avoid reducing the library to mere technologies or resources, in Heidegger's sense, and which will facilitate recognition of the library's larger role as a cultural and transformative institution:

\section{Library as Portal to the World}

\footnotetext{
${ }^{106}$ Salzburg Seminar, Libraries in the 21st Century, Vision of the Communal Role of Libraries (March 31, 2005), http://www1.law.umkc.edu/faculty/callister/Session422/statement.pdf. 
Besides the pragmatic recognition that many libraries serve more virtual visitors than physical patrons, the library must serve as a window to a wider world; allowing patrons to access unfamiliar places and ideas.

\section{Library as Social Knowledge Networks}

An organization's principle value is not its physical assets, but what the organization "knows"-including both the information it accesses and stores and the collective knowledge, wisdom, and social relationships of the organization's members-in this case the knowledge, skill, and relationships of the librarians.

\section{Library as User Behavior and Character}

The transformative impact of a library on its users and constituents is a prime justification for its continued existence. Not only should research skills and information literacy drive much of a library's effort, but the library's impact on the overall character and education of its users must be emphasized. Consequently, it will never do for law libraries to simply "train" students in legal research skills. ${ }^{107}$

\section{Library as Transformative and Communal Place}

As addressed in the Salzburg Statement, the law library provides sanctuary for human thought and expression and serves an important role in defining the respective cultures of the law schools and legal profession. It is a temple to which patrons may withdraw from the world, if only for a brief moment, to reorient their moral compasses, reflect on their ideals, remember who they

${ }^{107}$ For extensive discussion on the theme of training versus education, in the context of legal research instruction, see Paul Douglas Callister, supra note 13, at 7 (2003). 
are, and discover the entirely unexpected (including the intellectual and moral fiber at the heart of the profession).

In closing, remember the noble character of libraries and the transformative power of law. These twin, glorious institutions represent far more than resources for human consumption, subjugation and exploitation. It is not simply the futures of libraries and legal professions that are at stake, but the underpinnings of civilization and the continuing tenure of the rule of law. 